\title{
ANALISIS KORELASI KANONIK PADA HUBUNGAN ANTARA SOFT SKILLS TERHADAP PRESTASI BELAJAR MAHASISWA
}

\author{
Ni Putu Julianingsih ${ }^{1 \S}$, Eka N. Kencana ${ }^{2 \S}$, Komang Gde Sukarsa ${ }^{3 \S}$ \\ ${ }^{1}$ Program Studi Matematika, Fakultas MIPA - Universitas Udayana [Email: julianingsih.niputu@gmail.com ] \\ ${ }^{2}$ Program Studi Matematika, Fakultas MIPA - Universitas Udayana [Email: i.putu.enk@unud.ac.id ] \\ ${ }^{3}$ Program Studi Matematika, Fakultas MIPA - Universitas Udayana [Email: gedesukarsa@ unud.ac.id ] \\ ${ }^{\S}$ Corresponding Author
}

\begin{abstract}
The purpose of this study is to know the relationship between soft skills and learning achievement using canonical correlation analysis and to find out the dominant dimensions of soft skills and learning achievement using confirmatory factor analysis. The data used are primary data obtained by distributing questionnaires. The sampling technique used was proportional to size sampling with the number of respondents as many as 150 respondents. The results of the study with canonical correlation analysis showed that soft skills with learning achievement had a close relationship with canonical correlation values of 0.70397 . The results of the study with confirmatory factor analysis showed that the dominant dimensions of soft skills and learning achievement were flexibility with the percentage of the variance of $69.081 \%$ and cognitive percentage of the variance of $71.706 \%$.
\end{abstract}

Keywords: Confirmatory Factor Analysis, Canonical Correlation Analysis, Soft Skills, Learning Achievements.

\section{PENDAHULUAN}

Dewasa ini, mahasiswa harusnya memiliki soft skills sebagai bekal saat duduk di bangku perguruan tinggi maupun setelah lulus nanti. Ketika seorang mahasiswa sedang berdiskusi dengan mahasiswa lain mengenai tugas yang diberikan oleh dosen, diskusi tersebut mampu membuat mahasiswa lebih memahami tugas yang ada, sehingga mahasiswa memperoleh nilai yang baik. Keberhasilan prestasi belajar mahasiswa dapat terlihat dari soft skills yang dimilikinya. Namun, hubungan antara soft skills dengan prestasi belajar belum diketahui dengan jelas.

Menurut Syah (2006), prestasi belajar diukur dengan menggunakan tiga dimensi yaitu, ranah cipta (kognitif), ranah rasa (afektif), dan ranah karsa (psikomotor). Sedangkan menurut Performance DNA International (2001) soft skills diukur dengan menggunakan tujuh dimensi yaitu, personal effectiveness, flexibility, management, creativity/innovation, futuristic thinking, leadership, dan persuasion.

Hubungan antara prestasi belajar dan soft skills yang masing-masing memiliki tiga dimensi dan tujuh dimensi dapat dianalisis menggunakan analisis korelasi kanonik. Metode analisis korelasi kanonik merupakan salah satu teknik analisis variabel ganda untuk mengindentifikasi dan mengukur hubungan antara dua kelompok variabel (Johnson \& Wichern, 2007).

Mempertimbangkan masing-masing dimensi soft skills dan prestasi belajar merupakan variabel laten, maka setiap dimensi dari soft skills dan dimensi prestasi belajar memerlukan indikator untuk mengukurnya. Oleh sebab itu, analisis faktor digunakan terlebih dahulu, analisis faktor yang digunakan dalam penelitian ini adalah analisis faktor konfirmatori, karena indikator variabel laten yang digunakan pada dimensi soft skills dan dimensi prestasi belajar telah ditentukan berdasarkan pembenaran suatu teori.

Tujuan dari penelitian ini yaitu, untuk mengetahui model hubungan antara soft skills dengan prestasi belajar pada mahasiswa aktif di FMIPA UNUD dan untuk mengetahui dimensi yang menonjol dalam membentuk soft skills dan prestasi belajar pada mahasiswa aktif di FMIPA UNUD. 


\section{TINJAUAN PUSTAKA}

\subsection{Analisis Faktor}

Analisis faktor memiliki tujuan untuk mereduksi informasi yang terdapat dalam sejumlah variabel asal menjadi sekelompok variabel baru yang jumlahnya lebih sedikit, variabel baru yang terbentuk dinamakan faktor. Misalkan vektor acak $\boldsymbol{X}$, dengan banyak komponen $p$, mempunyai rataan $\boldsymbol{\mu}$, dan matriks kovarian $\boldsymbol{\Sigma}$ merupakan penyusunan model faktor. Secara khusus, model analisis faktor dalam notasi matriks adalah sebagai berikut:

$$
\underset{(\mathrm{p} \times 1)}{\mathbf{X}-\boldsymbol{\mu}}=\underset{(\mathrm{p} \times \mathrm{m})(\mathrm{m} \times 1)}{\mathbf{L}} \underset{(\mathrm{p} \times 1)}{\mathbf{F}}
$$

dengan $\boldsymbol{L}_{p m}$ disebut muatan (loading) dari peubah $\mathrm{ke}-p$ pada faktor $\mathrm{ke}-m$, sehingga matriks L disebut matriks muatan faktor (Johnson \& Wichern, 2007). Adapun tahapan analisis faktor sebagai berikut:

1. Memeriksa nilai uji Bartlett test of sphericity dan Kaiser Mayer Olkin (KMO), jika diperoleh nilai hasil uji Bartlett test of sphericity $<0,50$ maka terdapat korelasi antarvariabel pada matriks data. Kemudian, jika nilai $\mathrm{KMO}>0,50$ maka jumlah data yang diambil cukup untuk dilakukan analisis faktor.

2. Memeriksa nilai uji measure of sampling adequacy (MSA), jika diperoleh nilai MSA $>0,50$ maka korelasi antarindikator kuat dan tidak ada indikator yang dikeluarkan.

3. Memeriksa nilai factor loading $(h)$ dan nilai komunalitas $\left(h^{2}\right)$ dari setiap item. Nilai $h$ menunjukkan seberapa besar pengaruh faktor terhadap variabel, dan nilai $h^{2}$ menunjukkan jumlah variansi suatu indikator yang dapat dijelaskan oleh dimensi reflektornya. Jika diperoleh nilai $h^{2}>0,50$ maka faktor yang diperoleh dianggap dapat menjelaskan indikator yang ada (Hair et al., 2010).

\subsection{Analisis Korelasi Kanonik}

Analisis korelasi kanonik merupakan salah satu teknik analisis variabel ganda untuk mengindentifikasi dan mengukur hubungan antara dua kelompok variabel, yakni sekelompok $\mathrm{p}$ variabel $\mathbf{Y}\left(\mathrm{Y}_{1}, \mathrm{Y}_{2}, \cdots, \mathrm{Y}_{\mathrm{p}}\right)$ dengan sekelompok $\mathrm{q}$ variabel $\mathbf{X}\left(\mathrm{X}_{1}, \mathrm{X}_{2}, \cdots, \mathrm{X}_{\mathrm{q}}\right)$. Misalkan kelompok pertama dari $p$ variabel diwakili oleh ( $\mathrm{p} \times 1$ ) vektor acak Y. Kelompok kedua dari $q$ variabel diwakili oleh ( $\mathrm{q} \times 1$ ) vektor acak $\mathbf{X}$. Kombinasi linear dari dua kelompok variabel tersebut dapat dituliskan sebagai berikut (Johnson \& Wichern, 2007):

$$
\begin{aligned}
& \mathbf{U}=\mathrm{a}_{1} \mathbf{X}_{\mathbf{1}}+\mathrm{a}_{2} \mathbf{X}_{\mathbf{2}}+\cdots+\mathrm{a}_{\mathrm{q}} \mathbf{X}_{\mathbf{q}}=\underline{\mathrm{a}^{\prime} \mathbf{X}} \\
& \mathbf{V}=\mathrm{b}_{1} \mathbf{Y}_{\mathbf{1}}+\mathrm{b}_{2} \mathbf{Y}_{\mathbf{2}}+\cdots+\mathrm{b}_{\mathrm{p}} \mathbf{Y}_{\mathbf{p}}=\underline{\mathrm{b}^{\prime} \mathbf{Y}}
\end{aligned}
$$

Adapun korelasi kanonik diperoleh dengan perhitungan sebagai berikut:

$$
\begin{aligned}
\rho & =\operatorname{Corr}(\mathbf{U}, \mathbf{V}) \\
& =\frac{\operatorname{Cov}(\mathbf{U}, \mathbf{V})}{\sqrt{\operatorname{Var}(\mathbf{U})} \sqrt{\operatorname{Var}(\mathbf{V})}} \\
& =\frac{\underline{\mathbf{a}^{\prime} \boldsymbol{\Sigma}_{\mathrm{XY}} \underline{\mathrm{b}}}}{\sqrt{\underline{\mathbf{a}^{\prime} \boldsymbol{\Sigma}_{\mathrm{XX}} \underline{\mathrm{a}}} \sqrt{\underline{\mathrm{b}}^{\prime} \boldsymbol{\Sigma}_{\mathrm{YY}} \underline{\mathbf{b}}}}}
\end{aligned}
$$

\section{METODE PENELITIAN}

\subsection{Jenis dan Sumber Data}

Penelitian ini dilaksanakan di lingkungan FMIPA UNUD. Waktu penelitian dilakukan pada bulan Mei-Agustus 2018. Pada penelitian ini, data yang digunakan adalah data sekunder dan data primer, yaitu data jumlah mahasiswa aktif FMIPA UNUD semester genap tahun ajaran 2017/2018 dan data yang diperoleh secara langsung dari penyebaran kuesioner kepada mahasiswa aktif FMIPA UNUD.

Sebelum itu, validitas item dan reabilitas kuesioner diperiksa dengan menyebarkan kuesioner kepada 30 responden di lingkungan FMIPA. Item yang tidak valid dieliminasi, sehingga yang tersisa adalah item-item yang valid sebagai refleksi dari ketiga dimensi prestasi belajar dan ketujuh dimensi soft skills.

\subsection{Ukuran dan Sampling Technique}

Populasi yang digunakan dalam penelitian ini adalah seluruh mahasiswa aktif FMIPA UNUD semester genap tahun ajaran 2017/2018. Sampel yang digunakan dalam penelitian ini diambil menggunakan metode probability proportional to size sampling, yaitu probabilitas pengambilan sampel dipilih secara proporsional dengan ukuran total populasi. Kemudian untuk tahap kedua digunakan random sampling, namun jumlah sampling sebanding dengan ukuran populasi. Jumlah sampel yang diambil sebanyak 150 orang, hal ini dilakukan dengan memperhatikan pendapat menurut Hair et al. (2010), yang menyatakan bahwa jumlah sampel minimal adalah 5 kali dari jumlah item pertanyaan yang terdapat kuesioner. 


\subsection{Operasionalisasi Variabel}

Ketiga dimensi prestasi belajar dan ketujuh dimensi soft skills pada penelitian ini dioperasionalisasikan ke dalam item-item pernyataan yang disusun dengan menggunakan skala interval, dengan 1 menunjukkan pendapat yang paling negatif dan 5 menunjukkan pendapat yang paling positif. Operasionalisasi masing-masing dimensi prestasi belajar dan soft skills ditunjukkan pada Tabel 1.

Tabel 1. Operasionalisasi Dimensi Prestasi Belajar dan Dimensi Soft skills

\begin{tabular}{|c|c|}
\hline Kode & Deskripsi pernyataan \\
\hline & Personal effectiveness \\
\hline$X_{11}$ & Percaya diri \\
\hline$X_{12}$ & Belajar dari kesalahan \\
\hline \multirow[t]{2}{*}{$X_{13}$} & Menyelesaikan tugas dalam tekanan \\
\hline & Flexibility \\
\hline$X_{21}$ & Memiliki rencana cadangan \\
\hline$X_{22}$ & Cepat akrab dengan orang baru \\
\hline \multirow[t]{2}{*}{$X_{23}$} & Mudah beradaptasi \\
\hline & Management \\
\hline$X_{31}$ & Memprioritaskan kegiatan \\
\hline$X_{32}$ & Membagi waktu setiap kegiatan \\
\hline \multirow[t]{2}{*}{$X_{33}$} & Melaksanakan kegiatan sesuai jadwal \\
\hline & Creativity / innovation \\
\hline$X_{41}$ & Memberikan ide/gagasan \\
\hline$X_{42}$ & Memiliki alternatif lain \\
\hline \multirow[t]{2}{*}{$X_{43}$} & Menjelaskan sesuatu dengan sederhana \\
\hline & Futuristic thinking \\
\hline$X_{51}$ & Berpikir sebelum bertindak \\
\hline$X_{52}$ & Melakukan tindakan antisipasi \\
\hline \multirow[t]{2}{*}{$X_{53}$} & Memiliki tujuan hidup \\
\hline & Leadership \\
\hline$X_{61}$ & Menerima kritik dan saran \\
\hline$X_{62}$ & Memberikan orang lain kepercayaan \\
\hline \multirow[t]{2}{*}{$X_{63}$} & Memiliki kemampuan memotivasi \\
\hline & Persuasion \\
\hline$X_{71}$ & Menggunakan alasan logis \\
\hline$X_{72}$ & Memanfaatkan kesamaan orang lain \\
\hline \multirow{2}{*}{$X_{73}$} & Mempunyai pengetahuan umum \\
\hline & Kognitif \\
\hline$Y_{11}$ & Memperhatikan materi perkuliahan \\
\hline$Y_{12}$ & Mengingat materi perkuliahan \\
\hline \multirow[t]{2}{*}{$Y_{13}$} & Memahami materi perkuliahan \\
\hline & Afektif \\
\hline$Y_{21}$ & Menanggapi materi perkuliahan \\
\hline$Y_{22}$ & Ikut mengerjakan tugas kelompok \\
\hline \multirow[t]{2}{*}{$Y_{23}$} & Menjawab pertanyaan dari dosen \\
\hline & Psikomotor \\
\hline$Y_{31}$ & Mengerjakan tugas dengan baik \\
\hline$Y_{32}$ & Menyelesaikan tugas sesuai prosedur \\
\hline$Y_{33}$ & Menyampaikan materi dengan jelas \\
\hline
\end{tabular}

\subsection{Teknik Analisis}

Tahapan analisis data dalam penelitian ini dijelaskan sebagai berikut:

1. Pemeriksaan validitas dan reliabilitas kuesioner, validitas dilakukan dengan memeriksa nilai korelasi setiap item dengan total item lainnya yang tergabung ke dalam dimensi yang sama, dan reliabilitas masingmasing dimensi diamati melalui nilai Cronbach Alpha $(\alpha)$.

2. Melakukan analisis faktor untuk mengetahui faktor-faktor yang memengaruhi soft skills dan faktor-faktor yang memengaruhi prestasi belajar.

3. Melakukan analisis korelasi kanonik untuk mengetahui hubungan antara antara soft skills dengan prestasi belajar mahasiswa.

\section{HASIL DAN PEMBAHASAN}

\subsection{Uji Validitas dan uji Reliabilitas}

Uji valididtas dan reliabilitas pada penelitian ini dilakukan pada 150 sampel penelitian. Adapun hasil analisis uji validitas dan reabilitas untuk setiap indikator pada dimensi soft skills diperlihatkan pada Tabel 2.

Tabel 2. Hasil uji validitas dan reabilitas soft skills

\begin{tabular}{|c|c|c|}
\hline Dimensi & Kode & Nilai $\rho$ \\
\hline \multirow{3}{*}{$\begin{array}{l}\text { Personal } \\
\text { effectiveness } \\
(\alpha=0,614)\end{array}$} & $X_{11}$ & 0,321 \\
\hline & $X_{12}$ & 0,396 \\
\hline & $X_{13}$ & 0,588 \\
\hline \multirow{3}{*}{$\begin{array}{l}\text { Flexibility } \\
(\alpha=0,723)\end{array}$} & $X_{21}$ & 0,345 \\
\hline & $X_{22}$ & 0,716 \\
\hline & $X_{23}$ & 0,649 \\
\hline \multirow{3}{*}{$\begin{array}{l}\text { Management } \\
(\alpha=0,672)\end{array}$} & $X_{31}$ & 0,589 \\
\hline & $X_{32}$ & 0,527 \\
\hline & $X_{33}$ & 0,385 \\
\hline \multirow{3}{*}{$\begin{array}{l}\text { Creativity / } \\
\text { innovation } \\
(\alpha=0,707)\end{array}$} & $X_{41}$ & 0,566 \\
\hline & $X_{42}$ & 0,609 \\
\hline & $X_{43}$ & 0,425 \\
\hline \multirow{3}{*}{$\begin{array}{l}\text { Futuristic thinking } \\
(\alpha=0,770)\end{array}$} & $X_{51}$ & 0,700 \\
\hline & $X_{52}$ & 0,570 \\
\hline & $X_{53}$ & 0,549 \\
\hline \multirow{3}{*}{$\begin{array}{l}\text { Leadership } \\
(\alpha=0,741)\end{array}$} & $X_{61}$ & 0,716 \\
\hline & $X_{62}$ & 0,515 \\
\hline & $X_{63}$ & 0,484 \\
\hline \multirow{3}{*}{$\begin{array}{l}\text { Persuasion } \\
(\alpha=0,826)\end{array}$} & $X_{71}$ & 0,711 \\
\hline & $X_{72}$ & 0,650 \\
\hline & $X_{73}$ & 0,708 \\
\hline
\end{tabular}

Sumber: Data Primer (2018)

Pada Tabel 2 dapat dilihat bahwa setiap indikator pada dimensi soft skills memiliki nilai koefisien $\rho \geq 0,30$ yang menyatakan setiap indikator tersebut valid dan nilai $\alpha \geq 0,60$ yang 
menyatakan setiap indikator pada dimensi soft skills yang dibentuk sudah reliabel.

Sedangkan hasil analisis uji validitas dan reabilitas untuk setiap indikator pada dimensi soft skills diperlihatkan pada Tabel 3.

Tabel 3. Hasil uji validitas dan reabilitas prestasi belajar

\begin{tabular}{l|c|c}
\hline \multicolumn{1}{c|}{ Dimensi } & Kode & Nilai $\rho$ \\
\hline \multirow{2}{*}{$\begin{array}{l}\text { Ranah cipta (kognitif) } \\
(\alpha=0,813)\end{array}$} & $Y_{11}$ & 0,635 \\
\cline { 2 - 3 } & $Y_{12}$ & 0,721 \\
\cline { 2 - 3 } & $Y_{13}$ & 0,641 \\
\hline \multirow{2}{*}{$\begin{array}{l}\text { Ranah rasa (afektif) } \\
(\alpha=0,783)\end{array}$} & $Y_{21}$ & 0,588 \\
\cline { 2 - 3 } & $Y_{22}$ & 0,641 \\
\cline { 2 - 3 } & $Y_{23}$ & 0,639 \\
\hline Ranah karsa & $Y_{31}$ & 0,721 \\
\hline psikomotor) & $Y_{32}$ & 0,778 \\
\cline { 2 - 3 }$(\alpha=0,841)$ & $Y_{33}$ & 0,625 \\
\hline
\end{tabular}

Sumber: Data Primer (2018)

Pada Tabel 3 memperlihatkan setiap indikator pada dimensi prestasi belajar memiliki nilai koefisien $\rho \geq 0,30$ yang menyatakan setiap indikator tersebut valid dan nilai $\alpha \geq$ 0,60 yang menyatakan setiap indikator pada dimensi prestasi belajar yang dibentuk sudah reliabel (Hair et al., 2010).

\subsection{Analisis Faktor}

Pada penelitian ini menggunakan analisis faktor konfirmatori untuk mengetahui dominansi dimensi prestasi belajar dan dimensi soft skills mahasiswa aktif di FMIPA UNUD.

\section{a. AF pada Dimensi Personal Effectiveness}

Ringkasan hasil analisis faktor pada dimensi Personal Effectiveness ditunjukkan pada Tabel 4.

Tabel 4. Ringkasan Hasil AF Personal Effectiveness

\begin{tabular}{c|c|c|l|l}
\hline Kode & Nilai $h$ & Nilai $h^{2}$ & MSA & Ket \\
\hline$X_{11}$ & 0,751 & 0,564 & 0,711 & Layak \\
\hline$X_{12}$ & 0,796 & 0,634 & 0,656 & Layak \\
\hline$X_{13}$ & 0,851 & 0,724 & 0,614 & Layak \\
\hline \multicolumn{4}{l}{ Nilai KMO dan Matriks Data } & 0,652 \\
\hline \multicolumn{4}{l}{ Nilai $X^{2}$ Statistik Bartlett } & 91,310 \\
\hline
\end{tabular}

Sumber: Data Primer (2018)

Pada Tabel 4 dapat dilihat bahwa ketiga item dapat merefleksikan 64,093 persen keragaman dimensi, dengan item $X_{13}$ yang memiliki nilai factor loading dan komunalitas masing-masing sebesar 0,851 dan 0,724 merupakan item dominan yang terefleksikan pada dimensi ini. Menyelesaikan tugas dalam segala kondisi menjadi refleksi dominan Personal Effectiveness ditinjau dari dimensi soft skills menurut Performance DNA International (2001).

\section{b. AF pada Dimensi Flexibility}

Ringkasan hasil analisis faktor pada dimensi Flexibility ditunjukkan pada Tabel 5.

Tabel 5. Ringkasan Hasil AF Flexibility

\begin{tabular}{c|c|c|l|l}
\hline Kode & Nilai $h$ & Nilai $h^{2}$ & MSA & Ket \\
\hline$X_{21}$ & 0,709 & 0,503 & 0,839 & Layak \\
\hline$X_{22}$ & 0,886 & 0,786 & 0,598 & Layak \\
\hline$X_{23}$ & 0,885 & 0,784 & 0,598 & Layak \\
\hline \\
Nilai KMO dan Matriks Data & 0,635 \\
\hline
\end{tabular}

Sumber: Data Primer (2018)

Pada Tabel 5 dapat dilihat bahwa ketiga item dapat merefleksikan 69,081 persen keragaman dimensi, dengan item $X_{22}$ yang memiliki nilai factor loading dan komunalitas masing-masing sebesar 0,886 dan 0,786 merupakan item dominan yang terefleksikan pada dimensi ini. Cepat akrab dengan orang yang baru menjadi refleksi dominan Flexibility ditinjau dari dimensi soft skills menurut Performance DNA International (2001).

\section{c. AF pada Dimensi Management}

Ringkasan hasil analisis faktor pada dimensi Management ditunjukkan pada Tabel 6.

Tabel 6. Ringkasan Hasil AF Management

\begin{tabular}{c|c|c|l|l}
\hline Kode & Nilai $h$ & Nilai $h^{2}$ & MSA & Ket \\
\hline$X_{31}$ & 0,823 & 0,677 & 0,664 & Layak \\
\hline$X_{32}$ & 0,811 & 0,657 & 0,678 & Layak \\
\hline$X_{33}$ & 0,787 & 0,619 & 0,709 & Layak \\
\hline \multicolumn{4}{l}{ Nilai KMO dan Matriks Data } & 0,682 \\
\hline \multicolumn{4}{l}{ Nilai $X^{2}$ Statistik Bartlett } & 92,904 \\
\hline \multicolumn{4}{l}{ Sumberse Keragaman Terekstrasi } & 65,128 \\
\hline
\end{tabular}

Pada Tabel 6 dapat dilihat bahwa ketiga item dapat merefleksikan 65,128 persen keragaman dimensi, dengan item $X_{31}$ yang memiliki nilai factor loading dan komunalitas masing-masing sebesar 0,823 dan 0,677 merupakan item dominan yang terefleksikan pada dimensi ini. Memprioritaskan kegiatan dengan baik menjadi refleksi dominan Management ditinjau dari dimensi soft skills menurut Performance DNA International (2001). 


\section{d. AF pada Dimensi Creativity / Innovation}

Ringkasan hasil analisis faktor pada dimensi Creativity / Innovation ditunjukkan pada Tabel 7. Pada Tabel 7 dapat dilihat bahwa ketiga item dapat merefleksikan 66,185 persen keragaman dimensi, dengan item $X_{41}$ yang memiliki nilai factor loading dan komunalitas masing-masing sebesar 0,857 dan 0,735 merupakan item dominan yang terefleksikan pada dimensi ini. Memberikan gagasan untuk suatu permasalahan menjadi refleksi dominan Creativity / Innovation ditinjau dari dimensi soft skills menurut Performance DNA International (2001).

Tabel 7. Ringkasan Hasil AF Creativity

\begin{tabular}{|c|c|c|c|c|}
\hline Kode & Nilai $h$ & Nilai $h^{2}$ & MSA & Ket \\
\hline$X_{41}$ & 0,857 & 0,735 & 0,628 & Layak \\
\hline$X_{42}$ & 0,809 & 0,654 & 0,672 & Layak \\
\hline$X_{43}$ & 0,772 & 0,597 & 0,721 & Layak \\
\hline \multicolumn{4}{|c|}{ Nilai KMO dan Matriks Data } & 0,667 \\
\hline \multicolumn{4}{|c|}{ Nilai $X^{2}$ Statistik Bartlett } & 103,723 \\
\hline \multicolumn{4}{|c|}{ Persentase Keragaman Terekstrasi } & 66,185 \\
\hline
\end{tabular}

\section{e. AF pada Dimensi Futuristic Thinking}

Ringkasan hasil analisis faktor pada dimensi Futuristic Thinking ditunjukkan pada Tabel 8.

Tabel 8. Ringkasan Hasil AF Futuristic Thinking

\begin{tabular}{|c|c|c|c|c|}
\hline Kode & Nilai $h$ & Nilai $h^{2}$ & MSA & Ket \\
\hline$X_{51}$ & 0,857 & 0,734 & 0,638 & Layak \\
\hline$X_{52}$ & 0,827 & 0,684 & 0,666 & Layak \\
\hline$X_{53}$ & 0,773 & 0,597 & 0,743 & Layak \\
\hline \multicolumn{4}{|c|}{ Nilai KMO dan Matriks Data } & 0,674 \\
\hline \multicolumn{4}{|c|}{ Nilai $X^{2}$ Statistik Bartlett } & 110,228 \\
\hline \multicolumn{4}{|c|}{ Persentase Keragaman Terekstrasi } & 67,172 \\
\hline
\end{tabular}

Sumber: Data Primer (2018)

Pada Tabel 8 dapat dilihat bahwa ketiga item dapat merefleksikan 67,172 persen keragaman dimensi, dengan item $X_{51}$ yang memiliki nilai factor loading dan komunalitas masing-masing sebesar 0,857 dan 0,734 merupakan item dominan yang terefleksikan pada dimensi ini. Berpikir sebelum bertindak menjadi refleksi dominan Futuristic Thinking ditinjau dari dimensi soft skills menurut Performance DNA International (2001).

\section{f. AF pada Dimensi Leadership}

Ringkasan hasil analisis faktor pada dimensi Leadership ditunjukkan pada Tabel 9. Pada Tabel 9 dapat dilihat bahwa ketiga item dapat merefleksikan 60,964 persen keragaman dimensi, dengan item $X_{62}$ yang memiliki nilai factor loading dan komunalitas masing-masing sebesar 0,831 dan 0,691 merupakan item dominan yang terefleksikan pada dimensi ini. Memberikan kepercayaan kepada orang lain menjadi refleksi dominan Leadership ditinjau dari dimensi soft skills menurut Performance DNA International (2001).

Tabel 9. Ringkasan Hasil AF Leadership

\begin{tabular}{|c|c|c|c|c|}
\hline Kode & Nilai $h$ & Nilai $h^{2}$ & MSA & Ket \\
\hline$X_{61}$ & 0,719 & 0,517 & 0,708 & Layak \\
\hline$X_{62}$ & 0,831 & 0,691 & 0,606 & Layak \\
\hline$X_{63}$ & 0,788 & 0,621 & 0,634 & Layak \\
\hline \multicolumn{4}{|c|}{ Nilai KMO dan Matriks Data } & 0,640 \\
\hline \multicolumn{4}{|c|}{ Nilai $X^{2}$ Statistik Bartlett } & 73,174 \\
\hline \multicolumn{4}{|c|}{ Persentase Keragaman Terekstrasi } & 60,964 \\
\hline
\end{tabular}

\section{g. AF pada Dimensi Persuasion}

Ringkasan hasil analisis faktor pada dimensi Persuasion ditunjukkan pada Tabel 10.

Tabel 10. Ringkasan Hasil AF Persuasion

\begin{tabular}{c|c|c|c|l}
\hline Kode & Nilai $h$ & Nilai $h^{2}$ & MSA & Ket \\
\hline$X_{71}$ & 0,821 & 0,675 & 0,681 & Layak \\
\hline$X_{72}$ & 0,792 & 0,627 & 0,722 & Layak \\
\hline$X_{73}$ & 0,836 & 0,700 & 0,664 & Layak \\
\hline \multicolumn{4}{l}{ Nilai KMO dan Matriks Data } & 0,687 \\
\hline \multicolumn{4}{l}{ Nilai $X^{2}$ Statistik Bartlett } & 103,632 \\
\hline \multicolumn{4}{l}{ Sumber Derage Keraganan Terekstrasi } & 66,712 \\
\hline
\end{tabular}

Pada Tabel 10 dapat dilihat bahwa ketiga item dapat merefleksikan 66,712 persen keragaman dimensi, dengan item $X_{73}$ yang memiliki nilai factor loading dan komunalitas masing-masing sebesar 0,836 dan 0,700 merupakan item dominan yang terefleksikan pada dimensi ini. Mempunyai pengetahuan umum menjadi refleksi dominan Persuasion ditinjau dari dimensi soft skills menurut Performance DNA International (2001).

\section{h. AF pada Dimensi Ranah Cipta}

Ringkasan hasil analisis faktor pada dimensi Ranah Cipta ditunjukkan pada Tabel 11.

Tabel 11. Ringkasan Hasil AF Ranah Cipta

\begin{tabular}{|c|c|c|c|c|}
\hline Kode & Nilai $h$ & Nilai $h^{2}$ & MSA & Ket \\
\hline$Y_{11}$ & 0,837 & 0,701 & 0,727 & Layak \\
\hline$Y_{12}$ & 0,853 & 0,727 & 0,703 & Layak \\
\hline$Y_{13}$ & 0,850 & 0,723 & 0,706 & Layak \\
\hline \multicolumn{4}{|c|}{ Nilai KMO dan Matriks Data } & 0,712 \\
\hline \multicolumn{4}{|c|}{ Nilai $X^{2}$ Statistik Bartlett } & 139,816 \\
\hline \multicolumn{4}{|c|}{ Persentase Keragaman Terekstrasi } & 71,706 \\
\hline
\end{tabular}


Pada Tabel 11 dapat dilihat bahwa ketiga item dapat merefleksikan 71,706 persen keragaman dimensi, dengan item $Y_{12}$ yang memiliki nilai factor loading dan komunalitas masing-masing sebesar 0,853 dan 0,727 merupakan item dominan yang terefleksikan pada dimensi ini. Mengingat materi perkuliahan yang diberikan dengan baik menjadi refleksi dominan Ranah Cipta ditinjau dari dimensi prestasi belajar menurut Syah (2006).

\section{i. AF pada Dimensi Ranah Rasa}

Ringkasan hasil analisis faktor pada dimensi Ranah rasa ditunjukkan pada Tabel 12.

Tabel 12. Ringkasan Hasil AF Ranah Rasa

\begin{tabular}{|c|c|c|c|c|}
\hline Kode & Nilai $h$ & Nilai $h^{2}$ & MSA & Ket \\
\hline$Y_{21}$ & 0,811 & 0,658 & 0,633 & Layak \\
\hline$Y_{22}$ & 0,735 & 0,540 & 0,714 & Layak \\
\hline$Y_{23}$ & 0,802 & 0,644 & 0,639 & Layak \\
\hline \multicolumn{4}{|c|}{ Nilai KMO dan Matriks Data } & 0,656 \\
\hline \multicolumn{4}{|c|}{ Nilai $X^{2}$ Statistik Bartlett } & 73,066 \\
\hline \multicolumn{4}{|c|}{ Persentase Keragaman Terekstrasi } & 61,363 \\
\hline
\end{tabular}

Pada Tabel 12 dapat dilihat bahwa ketiga item dapat merefleksikan 61,363 persen keragaman dimensi, dengan item $Y_{21}$ yang memiliki nilai factor loading dan komunalitas masing-masing sebesar 0,811 dan 0,658 merupakan item dominan yang terefleksikan pada dimensi ini. Menanggapi dengan baik materi perkuliahan menjadi refleksi dominan Ranah Rasa ditinjau dari dimensi prestasi belajar menurut Syah (2006).

\section{j. AF pada Dimensi Ranah Karsa}

Ringkasan hasil analisis faktor pada dimensi Ranah karsa ditunjukkan pada Tabel 13.

Tabel 13. Ringkasan Hasil Ranah Karsa

\begin{tabular}{|c|c|c|c|c|}
\hline Kode & Nilai $h$ & Nilai $h^{2}$ & MSA & Ket \\
\hline$Y_{31}$ & 0,852 & 0,725 & 0,628 & Layak \\
\hline$Y_{32}$ & 0,842 & 0,710 & 0,635 & Layak \\
\hline$Y_{33}$ & 0,742 & 0,550 & 0,768 & Layak \\
\hline \multicolumn{4}{|c|}{ Nilai KMO dan Matriks Data } & 0,661 \\
\hline \multicolumn{4}{|c|}{ Nilai $X^{2}$ Statistik Bartlett } & 106,550 \\
\hline \multicolumn{4}{|c|}{ Persentase Keragaman Terekstrasi } & 66,165 \\
\hline
\end{tabular}

Sumber: Data Primer (2018)

Pada Tabel 13 dapat dilihat bahwa ketiga item dapat merefleksikan 66,165 persen keragaman dimensi, dengan item $Y_{31}$ yang memiliki nilai factor loading dan komunalitas masing-masing sebesar 0,852 dan 0,725 merupakan item dominan yang terefleksikan pada dimensi ini. Mengerjakan tugas yang diberikan dengan baik dan benar menjadi refleksi dominan Ranah Karsa ditinjau dari dimensi prestasi belajar menurut Syah (2006).

\subsection{Analisis Korelasi Kanonik}

Dari tujuh faktor untuk dimensi soft skills dan tiga faktor untuk dimensi prestasi belajar tersebut, selanjutnya dianalisis dengan menggunakan analisis korelasi kanonik. Hal ini dilakukan untuk mengkaji hubungan antara dua kelompok variabel, yaitu kelompok dimensi prestasi belajar dengan kelompok dimensi soft skills. Adapun penjelasannya sebagai berikut:

1. Uji data analisis korelasi kanonik

Dalam kasus ini, tidak ada data yang tidak lengkap, sehingga uji missing values tidak dilakukan. Uji data pencilan dilakukan dengan boxplot untuk mendeteksi adanya pencilan dalam data penelitian. Adapun hasil pendeteksian pencilan dari boxplot diperlihatkan pada Tabel 14.

Tabel 14. Hasil Deteksi Pencilan

\begin{tabular}{l|c|c}
\hline \multicolumn{1}{c|}{ Dimensi } & Kode & $\begin{array}{c}\text { Nomor kasus (nilai } \\
\text { pencilan) }\end{array}$ \\
\hline \multirow{2}{*}{$\begin{array}{l}\text { Personal } \\
\text { effectiveness }\end{array}$} & $\mathrm{X}_{1}$ & $\begin{array}{c}61(-2,31716), \\
90(-2,39097)\end{array}$ \\
\cline { 3 - 3 } $\begin{array}{l}\text { Creativity } \\
\text { innovation }\end{array}$ & $\mathrm{X}_{4}$ & $\begin{array}{l}92(-2,3058), \\
97(-2,23402)\end{array}$ \\
\hline $\begin{array}{l}\text { Futuristic } \\
\text { thinking }\end{array}$ & $\mathrm{X}_{5}$ & $127(-2,85931)$ \\
\hline $\begin{array}{l}\text { Leadership } \\
\text { Persuasion }\end{array}$ & $\mathrm{X}_{6}$ & $\begin{array}{l}55(-3,1137), \\
142(-2,9453)\end{array}$ \\
\hline & $\mathrm{X}_{7}$ & $\begin{array}{l}62(-2,80806), \\
106(-2,50839)\end{array}$ \\
\cline { 2 - 2 } & & $29(-2,46405)$ \\
\hline
\end{tabular}

Sumber: Data Primer (2018)

Dalam penelitian ini penulis melakukan penghapusan (deletion), agar himpunan data benar-benar bebas dari outlier. Sehingga, dapat dilihat bahwa boxplot sesudah penghapusan pada Gambar 1 tidak lagi memperlihatkan adanya outlier.

2. Uji asumsi analisis korelasi kanonik

a. Linearitas, diperoleh nilai $R$ square $>\alpha(0,01)$ dan nilai Sig. $>\alpha(0,05)$ yang berarti bahwa asumsi linearitas terpenuhi.

b. Normal multivariat, diperoleh nilai $\mathrm{Z}_{\text {skewness }}$ dan $\mathrm{Z}_{\text {kurtosis }}>\alpha(0,05)$ yang menyatakan bahwa asumsi normalitas multivariat terpenuhi. 
c. Homokedastisitas, diperoleh nilai Sig. $>\alpha(0,05)$ yang menyatakan bahwa asumsi homokedastisitas terpenuhi.

d. Nonmultikolinearitas, diperoleh nilai tolerance $>0,01$ dan nilai VIF $>10$ yang berarti tidak ditemukan adanya gejala multikolinearitas.

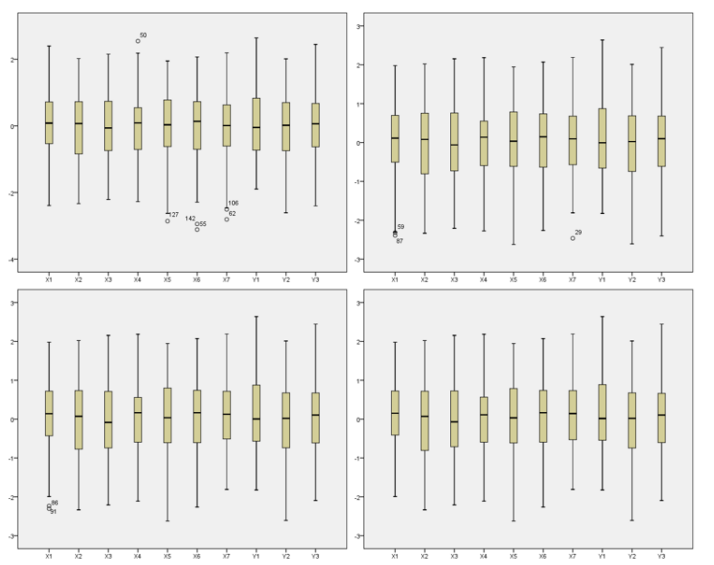

Gambar 1. Boxplot Sebelum dan Sesudah Penghapusan

3. Fungsi kanonik

Banyaknya fungsi kanonik yang terbentuk untuk tiga faktor dimensi prestasi belajar $(\mathrm{p}=3)$ dan tujuh faktor dimensi soft $\operatorname{skills}(\mathrm{q}=$ 7 ), yaitu $\min (3,7)=3$ fungsi. Adapun nilai eigen dan korelasi kanonik diperlihatkan pada Tabel 15.

Tabel 15. Hasil Nilai Eigen dan Korelasi Kanonik

\begin{tabular}{l|c|c|c}
\hline $\begin{array}{c}\text { Fungsi } \\
\text { ke }\end{array}$ & Eigenvalue & $\%$ & $\begin{array}{c}\text { Canon } \\
\text { Cor. }\end{array}$ \\
\hline 1 & 0,98246 & 89,17953 & 0,70397 \\
\hline 2 & 0,07647 & 6,94125 & 0,26653 \\
\hline 3 & 0,04274 & 3,87922 & 0,20245 \\
\hline \multicolumn{2}{|c|}{ Sumber: Data Primer $(2018)$}
\end{tabular}

Pada Tabel 15 dapat dilihat bahwa fungsi pertama mengakomodasikan 89,17953\% hubungan kanonikal, fungsi kedua mengakomodasikan $6,94125 \%$ hubungan kanonikal, dan fungsi ketiga mengakomodasikan 3,87922\% hubungan kanonikal. Korelasi kanonikal pada fungsi pertama, yaitu 0,70397 lebih besar dibandingkan dengan korelasi fungsi kedua dan ketiga. Dapat disimpulkan bahwa fungsi pertama lebih berarti dibandingkan fungsi yang lain.

\section{Uji signifikansi analisis korelasi kanonik}

Ada dua pengujian signifikansi yang diujikan dalam analisis korelasi kanonik yaitu uji korelasi kanonik secara bersama dan uii korelasi kanonik secara parsial (Johnson \& Wichern, 2007). Adapun penjelasannya sebagai berikut:

a. Uji korelasi kanonik secara bersama

Setelah melakukan pengujian secara bersama-sama, diketahui bahwa hubungan antarvariabel signifikan, sehingga pengujian dapat dilanjutkan.

\section{b. Uji korelasi kanonik secara parsial}

Berdasarkan uji parsial diketahui bahwa nilai signifikan untuk fungsi kanonik pertama $<\alpha(0.05)$ yang menyatakan bahwa adanya hubungan yang signifikan. Kemudian, untuk fungsi kanonik yang $>\alpha(0.05)$ tidak diproses atau diabaikan karena menunjukkan hubungan yang tidak signifikan.

\section{Interpretasi fungsi kanonik}

Menurut Hair et al. (2010), interpretasi yang dapat dilakukan dalam analisis korelasi kanonik adalah terhadap bobot kanonik (canonical weight), muatan kanonik (canonical loadings) dan muatan silang kanonik (canonical cross loadings). Adapun hasil interpretasi fungsi kanonik diperlihatkan pada Tabel 16.

Tabel 16. Hasil Interpretasi Fungsi Kanonik

\begin{tabular}{l|c|c|c|c}
\hline \multicolumn{2}{l|}{ Dimensi } & $\begin{array}{c}\text { Bobot } \\
\text { Kanonik }\end{array}$ & $\begin{array}{c}\text { Muatan } \\
\text { Kanonik }\end{array}$ & $\begin{array}{c}\text { Muatan } \\
\text { Silang } \\
\text { Kanonik }\end{array}$ \\
\hline $\mathbf{X}$ & $x_{1}$ & $-0,410$ & $-0,784$ & $-0,552$ \\
\cline { 2 - 5 } & $x_{2}$ & $-0,049$ & $-0,476$ & $-0,335$ \\
\cline { 2 - 5 } & $x_{3}$ & 0,034 & $-0,481$ & $-0,338$ \\
\cline { 2 - 5 } & $x_{4}$ & $-0,416$ & $-0,821$ & $-0,578$ \\
\cline { 2 - 5 } & $x_{5}$ & $-0,165$ & $-0,726$ & $-0,511$ \\
\cline { 2 - 5 } & $x_{6}$ & $-0,131$ & $-0,640$ & $-0,451$ \\
\cline { 2 - 5 } & $x_{7}$ & $-0,163$ & $-0,770$ & $-0,542$ \\
\hline \multirow{4}{*}{$Y$} & $y_{1}$ & $-0,375$ & $-0,827$ & $-0,583$ \\
\cline { 2 - 5 } & $y_{2}$ & $-0,222$ & $-0,791$ & $-0,557$ \\
\cline { 2 - 5 } & $y_{3}$ & $-0,565$ & $-0,910$ & $-0,641$ \\
\hline
\end{tabular}

Sumber: Data Primer (2018)

Pada Tabel 16 dapat dilihat bahwa hasil interpretasi fungsi kanonik yang menyatakan bahwa variabel yang mempunyai kontribusi relatif besar terhadap dimensi soft skills adalah Creativity/innovation. Sedangkan, variabel yang mempunyai kontribusi relatif besar terhadap dimensi prestasi belajar adalah Ranah karsa (psikomotor).

\section{KESIMPULAN}

Analisis korelasi kanonik menunjukkan bahwa terdapat hubungan yang positif dan signifikan antara soft skills dengan prestasi pada 
mahasiswa aktif di FMIPA UNUD. Hal ini ditunjukkan dengan total keragaman korelasi kanonikal pada fungsi pertama, yaitu $89,17953 \%$ dengan nilai korelasi kanonik sebesar 0,70397.

Analisis faktor menunjukkan bahwa indikator yang terdapat dalam ketujuh dimensi soft skills menurut Performance DNA International (2001) layak digunakan dalam mengukur soft skills pada mahasiswa aktif di FMIPA UNUD. Adapun faktor atau dimensi yang menonjol dalam membentuk soft skills tersebut adalah flexibility dengan nilai eigen 2,072 dan persentase variansi sebesar 69,081\%.

Selain itu, analisis faktor juga menunjukkan bahwa indikator yang terdapat dalam ketiga dimensi prestasi belajar menurut Menurut Syah (2006) layak digunakan dalam mengukur prestasi belajar pada mahasiswa aktif di FMIPA UNUD. Adapun faktor atau dimensi yang menonjol dalam membentuk prestasi belajar tersebut adalah ranah cipta (kognitif) dengan nilai eigen 2,151 dan persentase variansi sebesar $71,706 \%$.

\section{DAFTAR PUSTAKA}

Hair Jr., J. F., Black, W. C., Babin, B. J., \& Anderson, R. E. 2010. Multivariate Data Analysis (7nd ed.). United States of America: Pearson Education Limited.

Johnson, R. A., \& Wichern, D. W. 2007. Applied Multivariate Statistical Analysis (6nd ed.). United States of America: Pearson Prentice Hall.

Performance DNA International. 2001. Identifying, Prioritizing and Calibrating Performance Criteria Personal Soft Skills Indicator. Excel Group Development.

Syah, M. 2006. Psikologi Belajar. Jakarta: PT. Raja Grafindo Persada. 